\title{
Effect terminologie van houdbaarheidsdata van lang houdbare producten op weggooigedrag van consumenten
}

BO-projecten 20-015-031 en 20-015-032

December 2016

Nancy Holthuysen Stefanie Kremer Hilke Bos-Brouwers

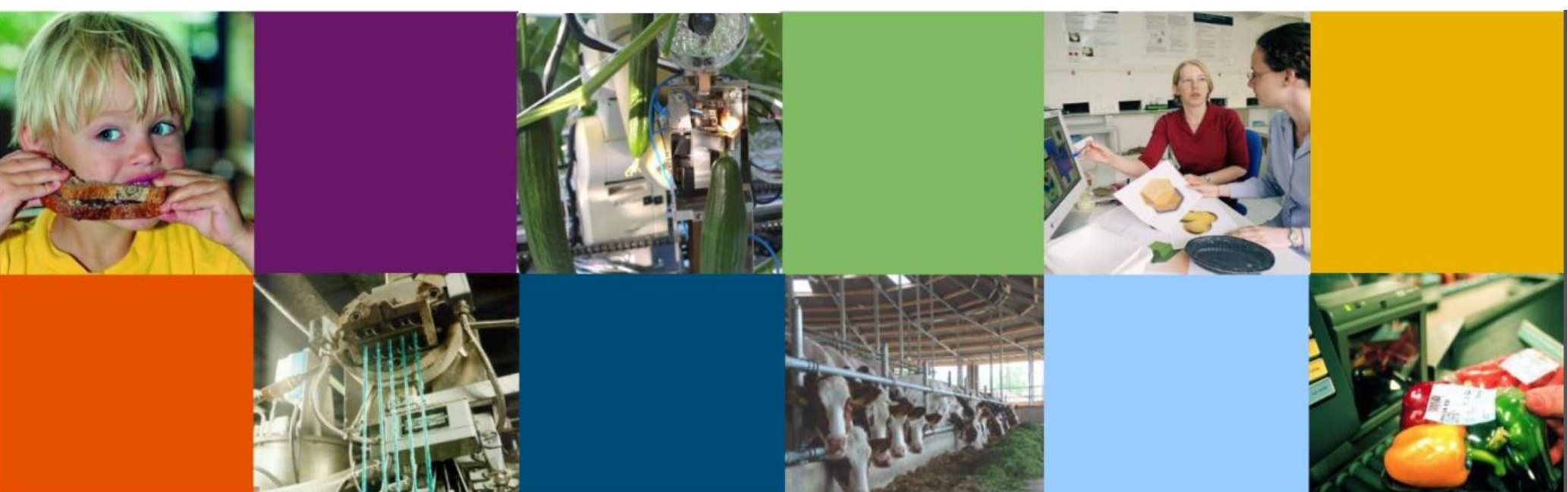




\section{Colofon}

Titel Effect van houdbaarheidsdata van lang houdbare producten op weggooigedrag van consumenten

Auteur(s) Nancy Holthuysen, Stefanie Kremer, Hilke Bos-Brouwers

Nummer Wageningen Food \& Biobased Research 1709

ISBN-nummer

978-94-6343-085-2

Publicatiedatum

DOI: $10.18174 / 404605$

Versie Na goedkeuring Ministerie EZ - 27 maart 2017

Vertrouwelijk 1

OPD-code Nee

Goedgekeurd door

Review

n.v.t.

Judith van der Horst

Intern

Naam reviewer

Toine Timmermans

Financier

Ministerie Economische Zaken via BO-onderzoeksgelden

Opdrachtgever

Ministerie Economische Zaken - Directie PAV

Wageningen Food \& Biobased Research

P.O. Box 17

NL-6700 AA Wageningen

Tel: +31 (0)317 480084

E-mail: info.fbr@wur.nl

Internet: www.wur.nl/foodandbiobased-research

(C) Wageningen Food \& Biobased Research, instituut binnen de rechtspersoon Stichting Wageningen Research Alle rechten voorbehouden. Niets uit deze uitgave mag worden verveelvoudigd, opgeslagen in een geautomatiseerd gegevensbestand of openbaar gemaakt in enige vorm of op enige wijze, hetzij elektronisch, hetzij mechanisch, door fotokopieën, opnamen of enige andere manier, zonder voorafgaande schriftelijke toestemming van de uitgever. De uitgever aanvaardt geen aansprakelijkheid voor eventuele fouten of onvolkomenheden.

All rights reserved. No part of this publication may be reproduced, stored in a retrieval system of any nature, or transmitted, in any form or by any means, electronic, mechanical, photocopying, recording or otherwise, without the prior permission of the publisher. The publisher does not accept any liability for inaccuracies in this report. 


\section{Samenvatting}

Het beter begrijpen van verspillingsgedrag bij consumenten vormt een belangrijke sleutel tot het verminderen van voedselverspilling. Uit eerder onderzoek, zowel nationaal (o.a. Voedingscentrum/GfK, 2015), als Europees (bijv. Flash Eurobarometer 425 on Food waste and date marking, 2015), blijkt dat het niet juist interpreteren van houdbaarheidsdata door consumenten met grote regelmatigheid worden aangegeven als een van de belangrijkere oorzaken van voedselverspilling. Er is echter nog weinig bekend over de grootte van dit effect en welke invloed de gebruikte terminologie hierbij heeft. Daarom heeft het Ministerie van Economische Zaken opdracht gegeven aan Wageningen Food \& Biobased Research om te onderzoeken wat de effecten zijn van het inzetten van een alternatieve terminologie alsmede van het weglaten van houdbaarheidsdata bij lang houdbare voedselproducten op het weggooigedrag van consumenten.

De vraag die centraal staat is of het veranderen of weglaten van de nu gebruikte 'houdbaarheid'-terminologie (nl. “Tenminste Houdbaar Tot" - THT-datum) op lang houdbare producten mogelijk kan bijdragen aan het verminderen van voedselverspilling door huishoudens. Deze kwalitatieve verkenning is uitgevoerd in een experimentele setting d.m.v. sorteer-opdrachten, online visual surveys en het uitvoeren van focus-groep discussies onder een groep van 86 Nederlandse consumenten. De experimenten zijn uitgevoerd in een gecontroleerde omgeving. Er is geen onderzoek gedaan naar weggooigedrag o.b.v. kilogrammen die in de vuilnisbak belanden, maar naar het selecteren van producten die de respondenten weg zouden gooien in de experimentele setting.

De resultaten leveren nieuwe, indicatieve inzichten op hoe het veranderen van terminologie over houdbaarheidsdata - of het weglaten ervan - invloed kan hebben op het voorkomen van voedselverspilling. Met lang houdbare producten worden producten bedoeld die volgens de huidige wetgeving een THT datum (Tenminste Houdbaar Tot) voeren. Dit onderzoek beperkt zich tot een deel van deze producten, namelijk de producten die bij kamertemperatuur bewaard kunnen worden. Voorbeelden van dit type producten zijn: rijst, pasta, koffie, en soep in blik.

Dit onderzoek wijst erop dat respondenten minder producten weggooien indien er geen THT datum op de verpakking staat . Gemiddeld werd in dit experiment 39\% van de producten weggegooid indien de THT datum verstreken was. Indien er geen THT datum op de verpakking stond, werd er $27 \%$ van de producten weggegooid. Dit is een verschil van gemiddeld $12 \%$. De verschillen tussen de productcategorieën zijn echter groot.

Uit de resultaten t.a.v. het inzetten van alternatieve terminologie kwam naar voren dat respondenten 31\% minder weggooien indien de term "Lang houdbaar" op de verpakking staat (zonder vermelding van een specifieke datum). Hoewel respondenten minder producten weggooiden, gaven ze ook aan deze term niet prettig te vinden. Het biedt hen geen duidelijkheid over de voedselveiligheid en kwaliteit van het betreffende product. Deze onzekerheid blijkt een belangrijke invloed te hebben op het weggooigedrag van consumenten: kan ik dit product nog veilig eten en smaakt het wel goed? 
De conclusie van het onderzoek is dat zowel het weglaten van houdbaarheidsdata als het invoeren van een alternatieve term zou kunnen bijdragen aan het verminderen van voedselverspilling bij huishoudens. Het verdient aanbeveling om invoering hiervan gefaseerd te laten plaatsvinden. Het onderzoek wees namelijk uit dat bij een deel van de onderzochte productgroepen (suiker, rijst, meel, thee e.d.) respondenten deze onzekerheid niet ervaren. Bij deze producten lijkt het inzetten van de term "lang houdbaar" veelbelovend. Daarnaast dient aandacht te worden besteed aan het veranderen van de risicoperceptie van consumenten. Hiertoe zijn diverse mogelijkheden denkbaar, waaronder betere consumentenvoorlichting, informatievoorziening op de verpakking van het product zelf (evt. via QR-codes/smartphone applicaties). Hoe dit precies invulling zou moeten krijgen, zal nader onderzoek moeten uitwijzen. 


\section{Inhoudsopgave}

Samenvatting 4

1 Inleiding 7

2 Methoden $\quad 8$

2.1 Sorteertaak 8

2.2 Onlinetaak 9

$\begin{array}{lll}2.3 & \text { Focusgroep discussie } & 10\end{array}$

2.4 Deelnemers 10

2.5 Producten 11

3 Resultaten 12

3.1 Sorteertaak 12

3.2 Online taak 14

3.3 Focusgroep discussie 16

4 Discussie 18

5 Conclusies $\quad 19$

$\begin{array}{lr}\text { Referenties } & 20\end{array}$

Bijlage 1 Coverstories $\quad 21$ 


\section{Inleiding}

Voedselverspilling is een groot, complex en maatschappelijk probleem. Er wordt geschat dat wereldwijd ongeveer $1 / 3^{\mathrm{e}}$ van het geproduceerde voedsel niet wordt gegeten door mensen (FAO, 2013). De precieze cijfers hangen echter sterk af van de manier waarop er gemeten wordt en van welke definitie van voedselverspilling wordt uitgegaan. In Europa gaat het ongeveer om 88 Mton (eetbaar en niet eetbare delen van) voedsel dat jaarlijks verspild wordt. Dit is circa $20 \%$ van de totale consumptie. De cijfers voor Nederland geven aan dat in de hele voedselketen tussen de 1,91 en 2,63 miljoen ton wordt verspild, oftewel tussen de 114$157 \mathrm{~kg}$ per persoon aan (potentieel) vermijdbaar voedsel dat verspild wordt (Wageningen UR Food \& Biobased Research Vollebregts et al. 2016). Het aandeel aan vermijdbaar voedsel wat bij huishoudens wordt verspild ligt al een aantal jaar rond de 50 kilogram per persoon (Voedingscentrum, 2014). De Nederlandse overheid committeerde zich in 2009 al aan het terugdringen van voedselverspilling met 20\% in 2015 en volgt het Europese Circulaire Economiepakket dat is uitgebracht in december 2015. Hierin wordt gesteld dat het bereiken van het door de Verenigde Naties opgestelde "Sustainable Development Goal" (SDG) 12.3 in 2030 met het halveren van voedselverspilling bij retail en consumenten en het terugdringen van voedselverliezen eerder in de keten speerpunt van beleid zijn. Het vormgeven van deze uitdaging in concrete acties zal daarmee in de komende periode moeten plaatsvinden.

Het beter begrijpen van verspillingsgedrag bij consumenten vormt een belangrijke sleutel tot het verminderen van voedselverspilling. Uit eerder onderzoek, zowel nationaal (o.a Voedingscentrum, 2014), als Europees (bijv. Flash Eurobarometer on Food waste and date marking, 2015), blijkt dat het niet juist interpreteren van houdbaarheidsdata door consumenten met grote regelmatigheid worden aangegeven als een van de belangrijkere oorzaken van voedselverspilling. Er is echter nog weinig bekend over de grootte van dit effect en welke invloed de gebruikte terminologie hierbij precies heeft. Daarom heeft het Ministerie van Economische Zaken opdracht gegeven aan Wageningen Food \& Biobased Research om te onderzoeken wat de effecten zijn van het inzetten van een alternatieve terminologie alsmede het weglaten van houdbaarheidsdata op het weggooigedrag van consumenten t.a.v. lang houdbare voedselproducten.

De vraag die centraal staat is of het veranderen of weglaten van de nu gebruikte 'houdbaarheid'-terminologie (nl. "Tenminste Houdbaar Tot" - THT-datum) op lang houdbare producten kan bijdragen aan het verminderen van voedselverspilling door huishoudens. Deze eerste kwalitatieve verkenning is uitgevoerd in een experimentele setting d.m.v. sorteer-opdrachten, online visual surveys en het uitvoeren van focus-groep discussies onder een groep van 86 Nederlandse consumenten.

De resultaten leveren nieuwe inzichten op hoe het gebruik van houdbaarheidsdata en terminologie invloed kunnen hebben op het voorkomen van voedselverspilling.

Dit onderzoek beperkt zich tot lang houdbare producten in gesloten verpakking. Met lang houdbare producten worden producten bedoeld die volgens de huidige wetgeving een THT datum (Tenminste Houdbaar Tot) voeren. Dit onderzoek beperkt zich tot een deel van deze producten namelijk de producten die bij kamertemperatuur bewaard kunnen worden. Voorbeelden van dit type producten zijn: rijst, pasta, koffie, en soep in blik. 


\section{Methoden}

Om de onderzoeksvraag te kunnen beantwoorden is er een indicatief consumentenonderzoek uitgevoerd, bestaande uit 3 onderdelen:

1. Sorteer experiment in een van de onderzoeksruimtes van het Restaurant van de Toekomst in Wageningen

2. Online onderzoek

3. Focus groep discussies

In figuur 1 is de opzet van de studie schematisch weergegeven.

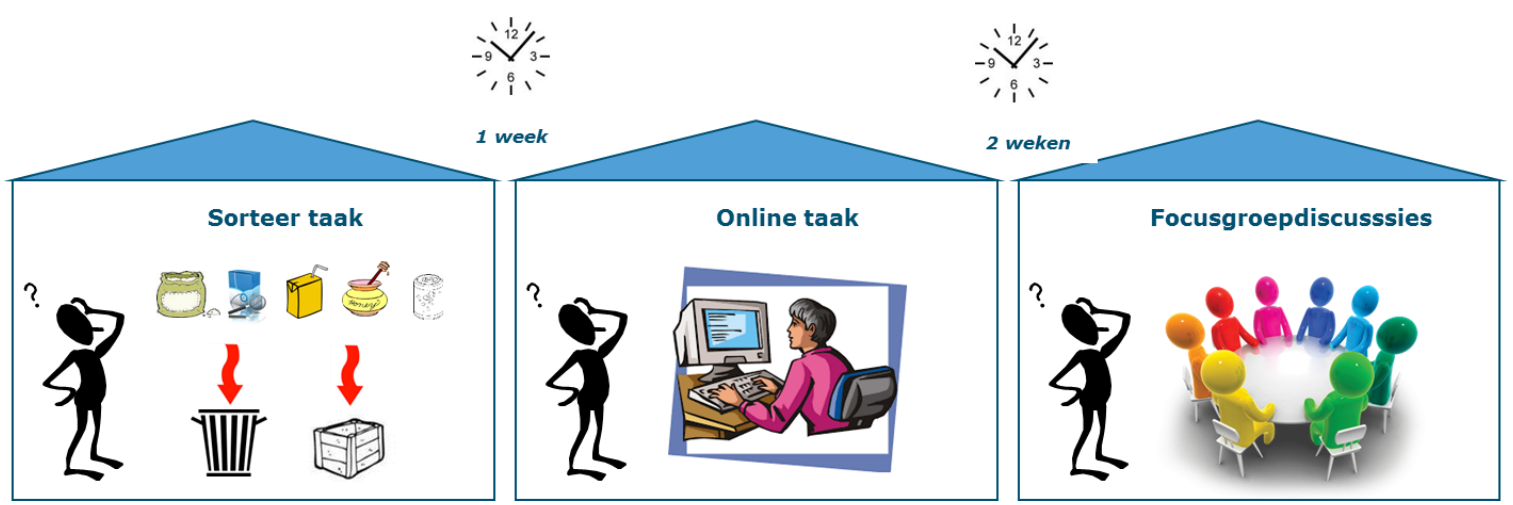

Figuur 1. Opzet van de studie

\subsection{Sorteertaak}

Bij het $1^{\mathrm{e}}$ onderdeel is er de focus gelegd op wat het effect is indien er geen datum op de verpakking staat.

De deelnemers kregen vooraf een korte "coverstory" te horen voordat ze begonnen aan de taak. Het doel van deze "coverstory" was om de deelnemers in een bepaalde "mindset" te krijgen zodat ze de tak op de juiste manier konden uitvoeren. De verschillende versies van de coverstory zijn weergegeven in bijlage 1. Afhankelijk van de leeftijd van de deelnemer werd voor een bepaalde versie van de coverstory gekozen.

In de kamer die de deelnemers betraden stond een kast met 60 producten. De 60 producten bestonden uit de 20 geselecteerde productcategorieën (zie tabel 3) steeds met een ander label (design: 20 producten x 3 labels).

De labels die op de verpakkingen zijn gebruikt, waren:

- Product dat nog houdbaar is (25\% voordat de THT versterken is)

- $\quad$ Product waarbij de THT datum verstreken is (25\% over de THT datum)

- $\quad$ Product zonder datum

Van ieder product zijn steeds 3 varianten gebruikt, zoals sinaasappelsap, appelsap en tomatensap. De producten zijn gebalanceerd aangeboden met steeds een ander informatielabel. Dit wil zeggen dat alle combinaties even vaak voorkwamen per kamer. Een voorbeeld is weergegeven in tabel 1. 
Tabel 1. Voorbeeld van aangeboden producten tijdens sorteertaak

\begin{tabular}{lll}
\hline Kamer $\mathbf{1}$ & Kamer 2 & Kamer 3 \\
\hline Sinaasappelsap-binnen THT & Sinaasappelsap-over THT & Sinaasappelsap-zonder datum \\
Appelsap-zonder datum & Appelsap-binnen THT & Appelsap-over THT \\
Tomatensap-over THT & Tomatensap-zonder THT & Tomatensap- binnen THT \\
\hline
\end{tabular}

Iedere deelnemer bezocht 1 van de 3 kamers. De deelnemers werd gevraagd om van de 60 producten die in de kast stonden te bepalen of ze het product wilden bewaren of wilden weggooien. Er werd uitdrukkelijk genoemd dat ze de producten ook mochten bewaren om aan iemand anders te geven (als ze het zelf bijvoorbeeld niet lusten). Verder mochten de deelnemers de verpakking niet open maken om te bepalen wat ze er mee gingen doen. In figuur 2 zijn enkele deelnemers te zien die bezig zijn met de sorteertaak.
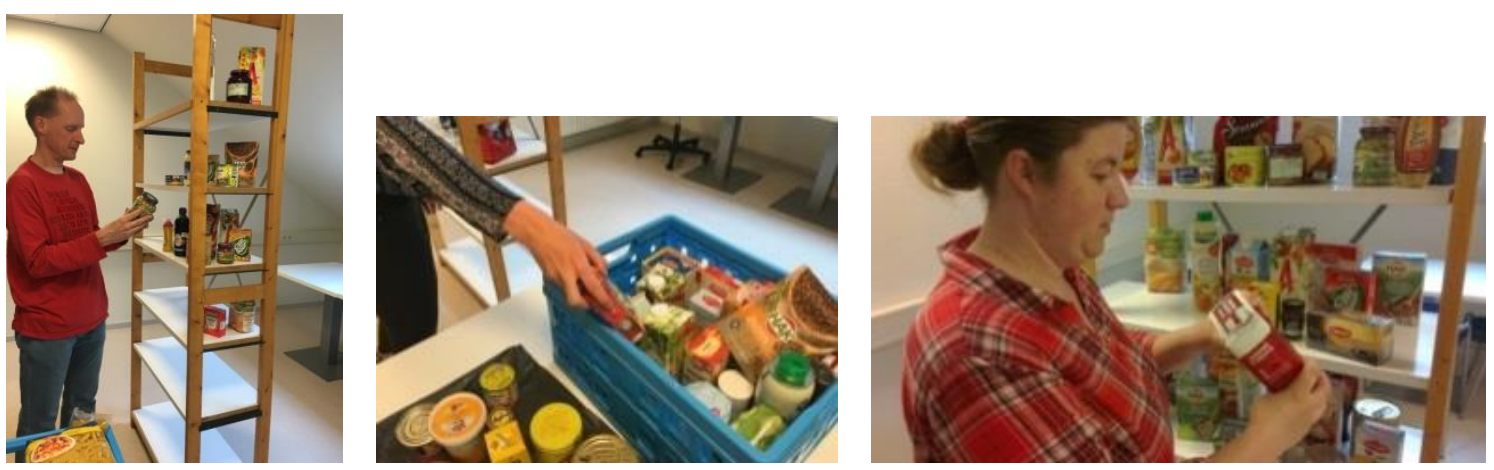

Figuur 2. Deelnemers tijdens de sorteertaak

\subsection{Onlinetaak}

De 10 producten die bij de sorteertaak het meeste weggegooid werden, zijn geselecteerd voor de onlinetaak (zie tabel 3). Bij de onlinetaak lag de focus op het effect van alternatieve termen op het weggooigedrag. Naast de huidige term "Tenminste Houdbaar Tot" zijn er 5 alternatieve termen onderzocht (zie tabel 2). De alternatieve termen in dit onderzoek zijn gekozen in overleg met de begeleidingscommissie.

Tabel 2. Overzicht van de alternatieve termen

Kwaliteit gegarandeerd tot [datum]

$\mathrm{Na}$ [datum] kijken, ruiken en proeven

Best te gebruiken voor [datum]

Geproduceerd op [datum]

Lang houdbaar 
De deelnemers kregen online een foto van een product te zien met daarbij één van de alternatieve termen. Er werd steeds gevraagd of ze dit product zouden bewaren of zouden weggooien. Alle producten tijdens de online taak waren $25 \%$ over de datum. In totaal moesten de deelnemers 60 combinaties beoordelen (design: 10 producten $\mathrm{x} 6$ termen)

Om de taak aantrekkelijk te houden, werd binnen een productcategorie steeds 6 verschillende varianten getoond, bijvoorbeeld blikje erwtjes, boontjes, worteltjes, mais, kidneybonen, of linzen. Dit is over de deelnemers gebalanceerd zodat alle termen en alle varianten even vaak getoond werden. In figuur 3 is een voorbeeld weergegeven van wat de deelnemers als taak te zien kregen.

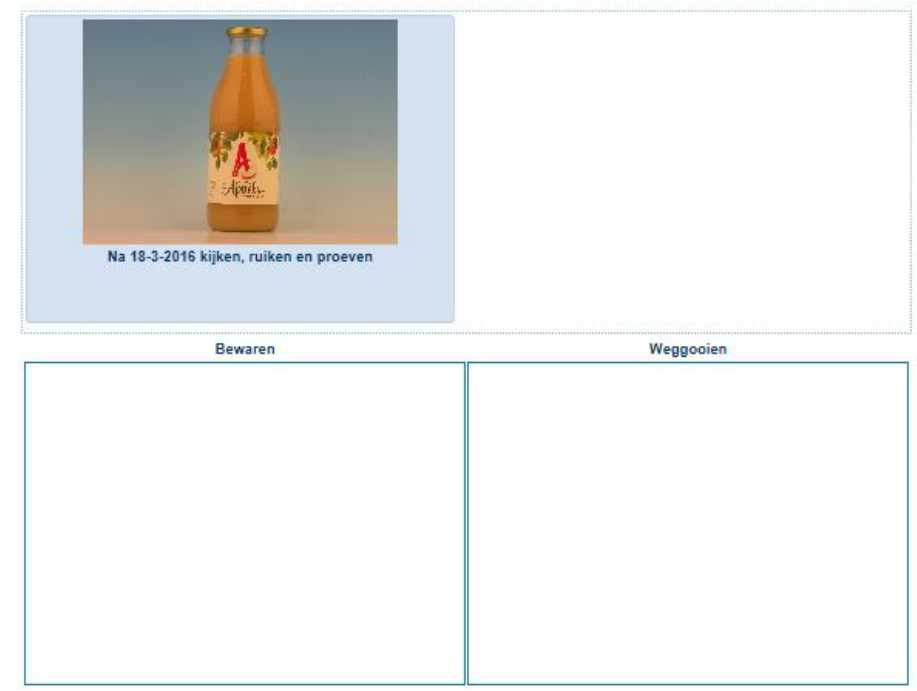

Figuur 3. Opdracht tijdens de online taak. Deelnemers konden met de muis het product naar de categorie bewaren of weggooien slepen.

\subsection{Focusgroep discussie}

Om meer inzicht te krijgen in de motieven en achtergronden van de deelnemers waarom ze bepaalde keuzes gemaakt hebben, zijn er focusgroepsdiscussies gehouden. Er zijn 2 groepsdiscussies van ieder 1,5 uur uitgevoerd. Aan het 1e groepsgesprek hebben 7 deelnemers deelgenomen die bij de sorteertaak het meeste weggegooid hadden. Aan het $2^{\mathrm{e}}$ groepsgesprek hebben 8 deelnemers deelgenomen die tijdens de online taak het sterkste reageerden op de alternatieve termen (positief dan wel negatief).

\subsection{Deelnemers}

Aan dit onderzoek hebben 86 deelnemers deelgenomen. Deelnemers werden niet geselecteerd, indien ze aangaven nooit lang houdbare producten weg te gooien. De deelnemers zijn geworven via de database van Wageningen Food \& Biobased Research en ontvingen een onkostenvergoeding van $€ 15$ voor hun deelname. De 15 deelnemers aan de focusgroep discussies ontvingen voor deelname aan de groepsdiscussie een aanvullende onkostenvergoeding van €15. De gemiddelde leeftijd was 40.5 jaar, range 19-76 jaar. $85 \%$ van de deelnemers was vrouw. 
Aangezien uit eerder onderzoek (o.a. Voedingscentrum/Motivaction o.b.v. consumer mentality profielen, 2015, en resultaten enquêtes voedselverspilling Voedingscentrum/GfK, 2015) is gebleken dat eenpersoonshuishoudens, gezinnen met (jonge) kinderen en jongeren (vooral onder de 25 jaar) gemiddeld meer voedsel verspillen dan andere groepen zijn deze respondenten geselecteerd voor deelname aan dit onderzoek. Een derde van de deelnemers had een eenpersoonshuishouden, $1 / 3^{e}$ een gezin met (jonge) kinderen en $1 / 3^{e}$ van de deelnemers was onder de 25 jaar.

\subsection{Producten}

In overleg met de begeleidingscommissie zijn er voor dit onderzoek 20 verschillende productcategorieën geselecteerd.

De producten in dit onderzoek zijn lang houdbare producten, mét THT datum, die niet in de uitzonderingenlijst van Bijlage X van EC Directive 1169/2011 staan (en dus al zonder datum mogen worden verkocht aan consumenten), aangevuld met overige, voor het onderzoek relevante lang houdbare producten. Hierbij is ook gekeken naar de lijst van meest weggegooide producten bij consumenten thuis (Voedingscentrum - Voedselverspilling door consumenten factsheet, 2014).

De producten die voor de online taak gekozen zijn bestaan uit de top 10 van producten die bij de sorteertaak het meeste weggegooid werden door de deelnemers.

Tabel 3. Overzicht van de producten in het onderzoek

\begin{tabular}{|c|c|c|c|}
\hline & Productcategorie & Sorteertaak & Online taak \\
\hline 1 & Blikjes vis & $\mathrm{x}$ & $\mathrm{x}$ \\
\hline 2 & (Fris)drank & $\mathrm{x}$ & \\
\hline 3 & (Gedroogde) groenten in pak/zak & $\mathrm{x}$ & $\mathrm{x}$ \\
\hline 4 & Groenten in blik & $\mathrm{x}$ & $\mathrm{x}$ \\
\hline 5 & Groenten in glas & $\mathrm{x}$ & $\mathrm{x}$ \\
\hline 6 & Honing & $\mathrm{x}$ & \\
\hline 7 & Koffie & $\mathrm{x}$ & \\
\hline 8 & Meel & $\mathrm{x}$ & $\mathrm{x}$ \\
\hline 9 & Pakken sap & $\mathrm{x}$ & $\mathrm{x}$ \\
\hline 10 & Pasta & $\mathrm{x}$ & \\
\hline 11 & Rijst & $\mathrm{x}$ & \\
\hline 12 & Sauzen & $\mathrm{x}$ & $\mathrm{x}$ \\
\hline 13 & Siroop & $\mathrm{x}$ & \\
\hline 14 & Soep & $\mathrm{x}$ & $\mathrm{x}$ \\
\hline 15 & Soeppoeder & $\mathrm{x}$ & $\mathrm{x}$ \\
\hline 16 & Stroop & $\mathrm{x}$ & \\
\hline 17 & Suiker & $\mathrm{x}$ & \\
\hline 18 & Thee & $\mathrm{x}$ & \\
\hline 19 & Tomatenpuree & $\mathrm{x}$ & $\mathrm{x}$ \\
\hline 20 & Zout & $\mathrm{x}$ & \\
\hline
\end{tabular}

Alle producten die in dit onderzoek gebruikt zijn voeren een A-merk..

1 "Verstrek.king voedselinformatie aan consumenten". Bijlage X betreft "Datum van minimale boudbaarheid, uiterste consumptiedatum en datum van invriezing". 


\section{Resultaten}

\subsection{Sorteertaak}

Van alle deelnemers is geturfd welke producten ze weg zouden gooien en welke producten ze zouden bewaren. In figuur 4 zijn de resultaten weergeven van het totaal aantal producten dat is weggegooid tijdens de sorteertaak, verdeeld over binnen, over of zonder THT-datum. In deze figuur is te zien dat producten waarvan de THT datum is verstreken significant meer weggegooid worden dan producten waar geen datum op staat. Producten waar geen datum op staat worden $12 \%$ minder weggegooid dan producten waarvan de datum verstreken is $(39 \%-27 \%)$.

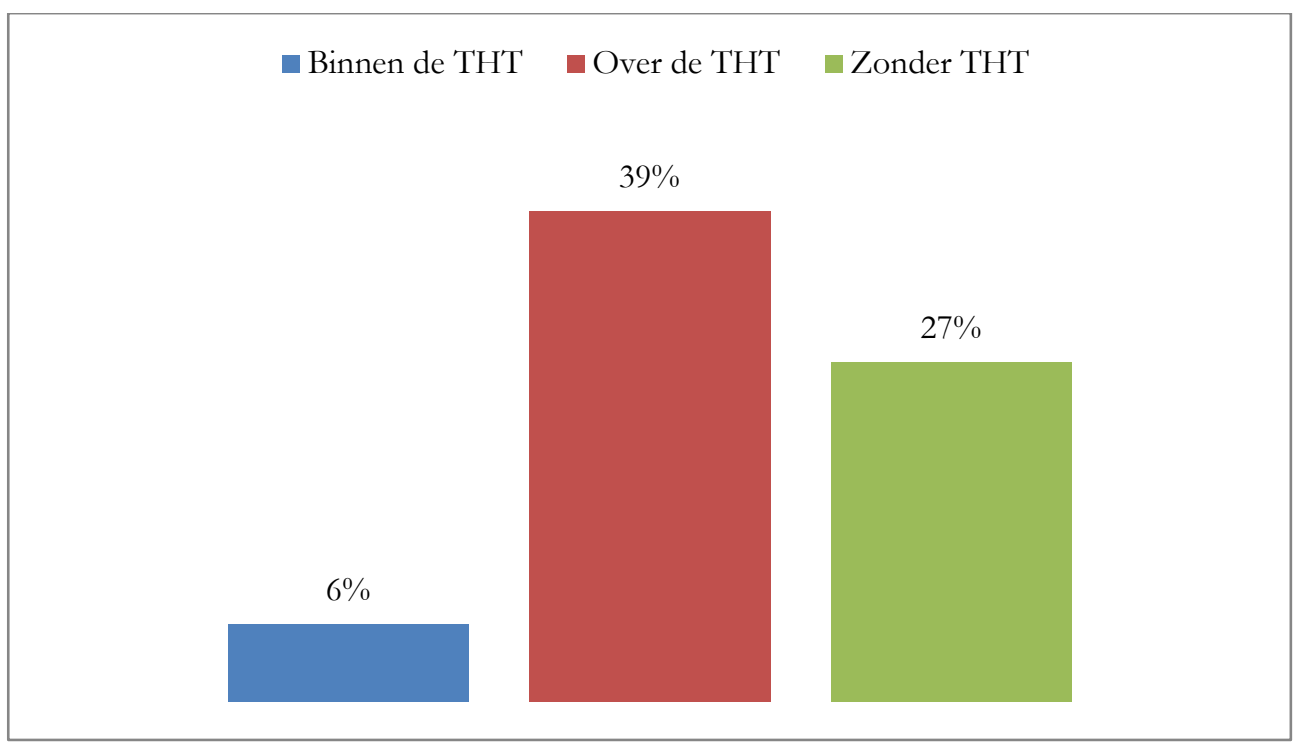

Figuur 4. Totaal aantal producten weggegooid tijdens de sorteertaak

De verschillen tussen de productcategorieën zijn echter groot. In tabel 4 is te zien dat stroop en tomatenpuree $23 \%$ minder weggegooid wordt als er geen datum op staat. Pakken sap daarentegen worden $5 \%$ vaker weggegooid als de datum ontbreekt. 
Tabel 4. Percentage producten dat weggegooid is tijdens de sorteertaak

\begin{tabular}{|c|c|c|c|c|c|}
\hline Categorie & over THT & zonder THT & p-value & significantie & verschil \\
\hline Stroop & $37 \%$ & $14 \%$ & 0.0001 & $* * *$ & $-23 \%$ \\
\hline Tomatenpuree & $50 \%$ & $27 \%$ & 0.0011 & $* *$ & $-23 \%$ \\
\hline Vis (blikjes) & $71 \%$ & $50 \%$ & 0.0009 & $* * *$ & $-21 \%$ \\
\hline Honing & $29 \%$ & $9 \%$ & 0.0002 & $* * *$ & $-20 \%$ \\
\hline Groenten in blik & $44 \%$ & $27 \%$ & 0.0035 & $* *$ & $-17 \%$ \\
\hline Soep & $66 \%$ & $51 \%$ & 0.0259 & $*$ & $-15 \%$ \\
\hline Soeppoeder pakjes & $48 \%$ & $34 \%$ & 0.0139 & $*$ & $-14 \%$ \\
\hline Meel & $43 \%$ & $29 \%$ & 0.0190 & $*$ & $-14 \%$ \\
\hline Pasta & $15 \%$ & $2 \%$ & 0.0055 & $* *$ & $-13 \%$ \\
\hline Rijst & $22 \%$ & $9 \%$ & 0.0153 & $*$ & $-13 \%$ \\
\hline Bonen/groente zak/pak & $45 \%$ & $33 \%$ & 0.1093 & n.s. & $-13 \%$ \\
\hline Suiker & $19 \%$ & $8 \%$ & 0.0433 & $*$ & $-10 \%$ \\
\hline (Fris)dranken & $30 \%$ & $21 \%$ & 0.1698 & n.s. & $-9 \%$ \\
\hline Thee & $16 \%$ & $8 \%$ & 0.1213 & n.s. & $-8 \%$ \\
\hline Koffie & $27 \%$ & $20 \%$ & 0.2636 & n.s. & $-7 \%$ \\
\hline Siroop & $36 \%$ & $29 \%$ & 0.4047 & n.s. & $-7 \%$ \\
\hline Sauzen & $52 \%$ & $47 \%$ & 0.4576 & n.s. & $-6 \%$ \\
\hline Groenten in glas & $57 \%$ & $52 \%$ & 0.5224 & n.s. & $-5 \%$ \\
\hline Zout & $7 \%$ & $3 \%$ & 0.3711 & n.s. & $-3 \%$ \\
\hline Sap pakken & $58 \%$ & $63 \%$ & 0.5708 & n.s. & $+5 \%$ \\
\hline Gemiddeld & $39 \%$ & $27 \%$ & & & $-12 \%$ \\
\hline
\end{tabular}

\footnotetext{
*** $\quad=$ significant $99.9 \%$, p-value 0.001

** $\quad=$ significant $95 \%$, p-value 0.05

* $\quad=$ significant $90 \%, \mathrm{p}$-value 0.1

n.s. $\quad=$ niet significant
}

De percentages in tabel 4 zijn als volgt berekend:

- Van de 86 deelnemers hebben 32 deelnemers de stroop weggegooid die over de datum was. Dit komt neer op een percentage van $37 \%$ : $((32 / 86)) * 100$

- Indien de stroop geen THT datum had gooide 12 deelnemers de stroop weg. Dit komt neer op een percentage van $14 \%:((12 / 86)) * 100$.

- Het verschil voor de productcategorie stroop bedraagt hier dus $23 \%$ (37\%-14\%).

De analyses zijn op dezelfde manier uitgevoerd voor de overige 19 productcategorieën. 
Figuur 5 is een grafische weergave van de vergelijking tussen weggooigedrag van consumenten van producten zonder en over de THT-datum. Hierin zijn significante verschillen te vinden tussen de verschillende productcategorieën.

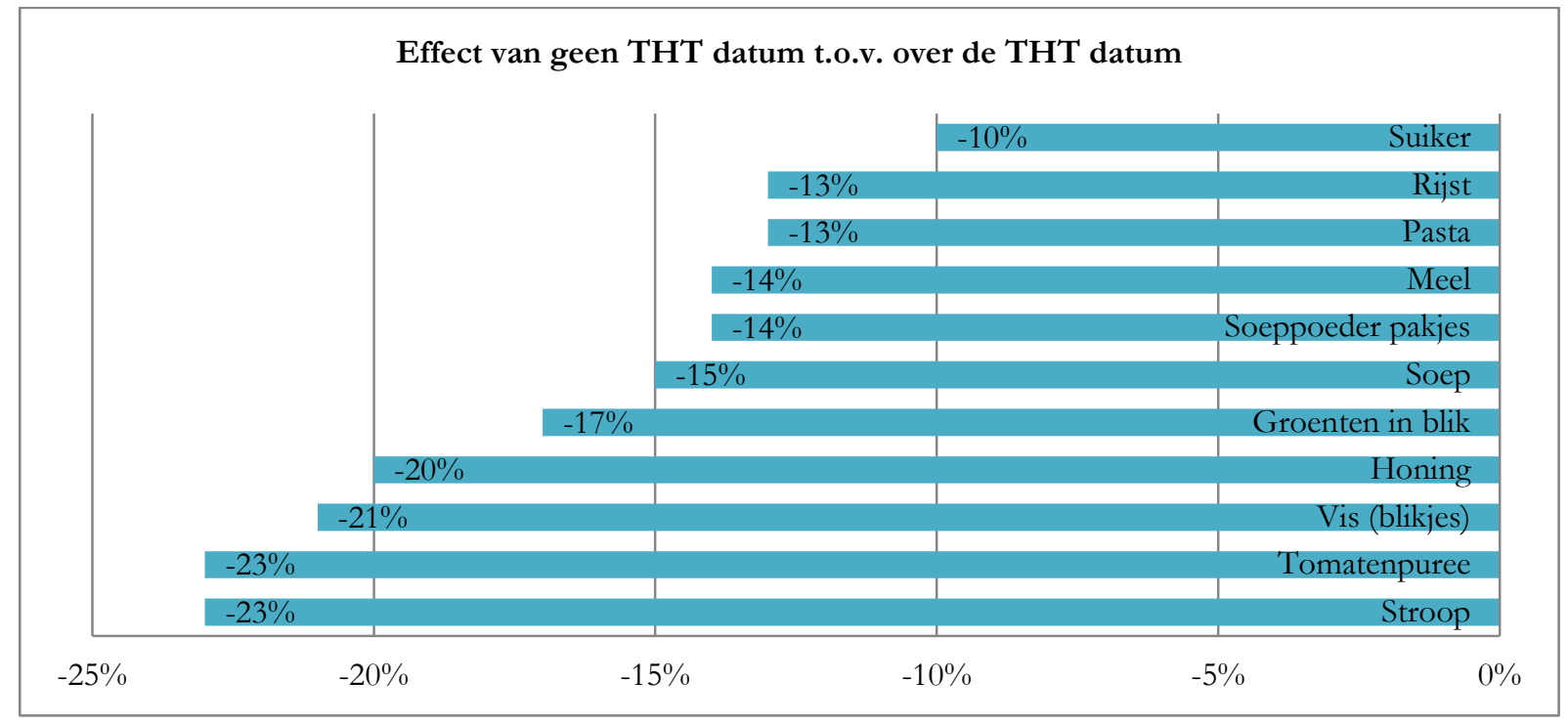

Figuur 5 Effect van geen THT datum t.o.v. over de THT datum

\subsection{Online taak}

Hieronder zijn de resultaten weergegeven van de online taak. Indien de term "Lang houdbaar" (zonder vermelding van een datum) op de verpakking staat, wordt er 31\% minder weggegooid t.o.v. de huidige term. Voor alle productgroepen wordt er dan minder weggegooid. Ook met de term "kwaliteit gegarandeerd tot [datum]" wordt er minder weggegooid (-5\%) (effect op de categorie sauzen). De termen “Geproduceerd op [datum]” en "Best te gebruiken voor [datum]” laten zien dat respondenten juist eerder geneigd zijn om een product weg te gooien. In figuur 6 is te zien hoeveel procent van de producten weggegooid werd per alternatieve term. De huidige term "Tenminste Houdbaar tot" is in rood weergegeven.

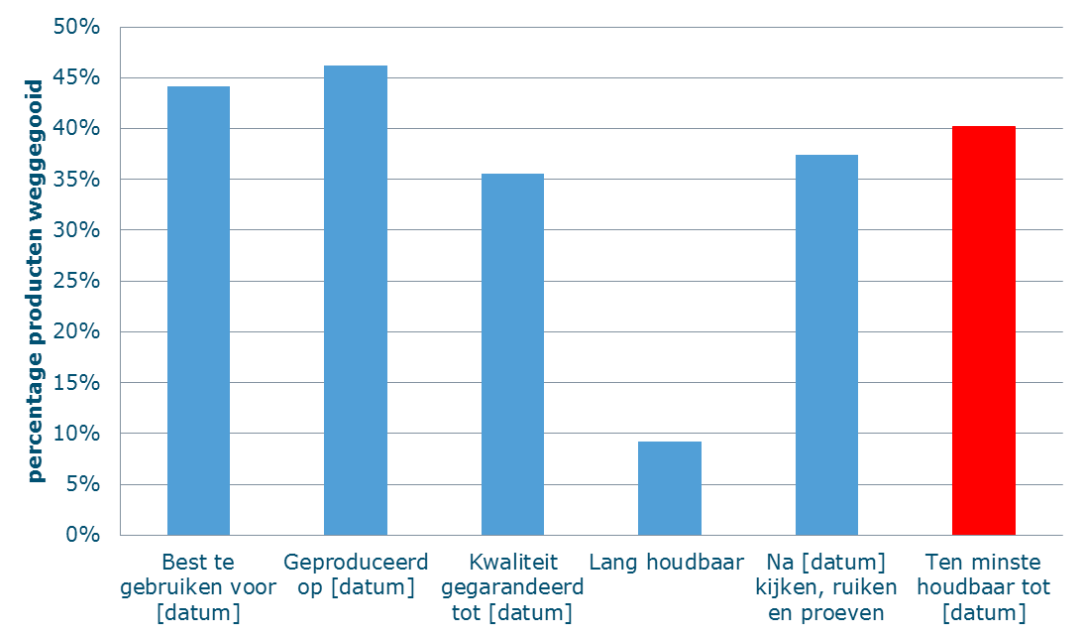

Figuur 6. Aantal producten weggegooid onder invloed van de alternatieve termen 
In tabel 5 zijn de verschillen per alternatieve term t.o.v. de huidige term "Tenminste houdbaar tot" weergegeven.

Tabel 5. Effect van de alternatieve termen op het weggooigedrag van de deelnemers

\begin{tabular}{|l|l|l|l|}
\hline Alternatieve term & Verschil t.o.v. THT & p-value & significantie \\
\hline Best te gebruiken voor [datum] & $+4 \%$ & 0.0447 & $*$ \\
\hline Geproduceerd op [datum] & $+6 \%$ & 0.00285 & $* *$ \\
\hline Kwaliteit gegarandeerd tot [datum] & $-5 \%$ & 0.0116 & $*$ \\
\hline Lang houdbaar (zonder datum) & $-31 \%$ & $<0.001$ & $* * *$ \\
\hline $\mathrm{Na}[$ datum] kijken, ruiken en proeven & $-3 \%$ & 0.1300 & n.s. \\
\hline
\end{tabular}

Hieronder volgt een voorbeeld hoe de percentages in tabel 5 berekend zijn:

- In geval van de term "Tenminste Houdbaar Tot" worden $40 \%$ van de producten weggegooid. Indien de term "Geproduceerd op" op de verpakking staat wordt er $46 \%$ van de producten weggegooid. Dit komt neer op een verschil van $6 \%(46 \%-40 \%)$

Alle bovenstaande resultaten zijn op basis van het gedrag dat de deelnemers daadwerkelijk vertonen als er bepaalde informatie op een product staat. Als er aan de deelnemers gevraagd wordt welke termen ze nu aantrekkelijk vinden, dan komen daar andere resultaten uit. Zo vinden de respondenten de term "Tenminste houdbaar tot [datum]" en "Kwaliteit gegarandeerd tot [datum]" aantrekkelijke termen en vinden ze de termen "Geproduceerd op [datum]" en 'Lang houdbaar" onaantrekkelijke termen.

Hoe aantrekkelijk de respondenten een bepaalde term vinden, lijkt niet noodzakelijkerwijs gerelateerd aan het potentiaal van de term om hun gedrag te beïnvloeden (in dit geval voedselverspilling te verminderen). 


\subsection{Focusgroep discussie}

In deze paragraaf worden de resultaten van de focusgroep discussie weergeven. Hierbij zijn alleen groepsresultaten weergegeven worden en worden er geen individuele meningen benoemd.

Deelnemers geven tijdens de focusgroep discussie aan dat er 2 hoofdmotieven zijn om houdbare producten weg te gooien. Dit zijn voedselveiligheid als de meest belangrijke en smaak als het $2^{\mathrm{e}}$ motief. Respondenten zijn bang om ziek te worden van producten waarvan de THT datum verstreken is. Dit geldt met name voor producten die verwerkte vlees, vis of ei bevatten. Producten waar ze een lager risico gevoel hebben zijn meel, koffie, thee, rijst, pasta, suiker, droge kruiden en frisdranken. Voor wat betreft achteruitgang in smaak speelt dit met name bij producten die geen verdere bewerking meer hebben, maar direct uit de verpakking gegeten worden.

Hoe mensen vervolgens bepalen of ze het product daadwerkelijk weg gaan gooien wordt bepaald door 3 factoren:

- $\quad$ Kennis \& Attitude van de consument zelf

- Verpakking/bewaarmethode

- $\quad$ Product/Ingrediënt

Als mensen weinig kennis hebben over hoe lang een product houdbaar is, dan zal dit leiden tot extra onzekerheid met als gevolg dat een product eerder weggegooid wordt. Respondenten die voldoende budget tot hun beschikking hebben of minder betrokken zijn bij het milieu, zullen ook geneigd zijn om een product eerder weg te gooien.

Producten met kwetsbare of natte ingrediënten zullen eerder weggegooid worden. Ook werd angegeven dat men producten die geen verdere bewerking nodig hebben, eerder zal weggooien.

\footnotetext{
Quotes:

"Ik geef liever twee euro uit aan een nieun product dan dat ik er ziek van word"

"Te ga bier dat even over de datum is echt niet aan mijn gasten geven. Dat is gênant"

"Tk, merkte dat ik wilde weten hoe het zit, ik heb te weinig kennis. En dan moet ik ook nog die fabrikant vertrouwen"

"Tk hoor op het nieuws dat rijst niet echt kan bederven. Waarom maken ze dat niet openbaar, dan zou ik bet veel minder snel weggooien"

"Duurzaambeid vind ik belangrijk. Als je iets weggooit, dan verspil je bet."
} 


\section{Alternatieve termen}

Als er gevraagd wordt naar de alternatieve termen dan zijn de meningen van de deelnemers verdeeld en is er niet echt één term die er duidelijk uitspringt.

De term “Geproduceerd op [datum]” wordt niet aantrekkelijk gevonden omdat er bij deze term heel veel kennis verondersteld wordt van de consument.

Hetzelfde is het geval voor de term "lang houdbaar". Ook deze term verondersteld veel kennis van de consument en is weinig concreet.

"Best te gebruiken voor [datum] "is een term die niet heel veel weerstand oproept maar ook niet heel favoriet is.

De term "Kwaliteit gegarandeerd tot [datum]" is voor een deel van de respondenten aantrekkelijk. Het geeft een vorm van zekerheid, maar roept bij sommigen de vraag op: en daarna dan?

Over de term "Na [datum] kijken, ruiken en proeven" zijn de meningen van de respondenten erg verdeeld. De mensen die iets meer productkennis hebben vinden dit een prettige term. De mensen met weinig productkennis vinden dit juist een term die veel onzekerheid oproept als: gevaarlijk, ruik ik nog wel goed?, proeven doe je niet als je twijfelt.

Samenvattend kan gezegd worden dat de respondenten behoefte hebben aan zekerheid en duidelijkheid en dat eventuele twijfel weggenomen wordt. De vraag is echter of dat met een term te realiseren valt of dat deze communicatie wellicht op een andere manier moet plaatsvinden.

\section{Geen datum}

De respondenten zijn het vrijwel unaniem eens dat het helemaal weglaten van een datum niet wenselijk is. Hierdoor ontstaat er nog minder duidelijkheid met als gevolg dat mensen onzeker worden. Het geeft geen enkele informatie en legt bovendien de volledige verantwoordelijkheid bij de consument en impliceert dat deze over kennis beschikt hoe lang een product bewaard kan worden. De respondenten vinden zelf dat ze niet over voldoende kennis beschikken c.q. zichzelf voldoende in staat achten de houdbaarheid te kunnen beoordelen.

Men kan zich voorstellen dat bij bepaalde droge producten een vermelding achterwege kan blijven (suiker, rijst, meel, thee etc.), maar bij het overgrote deel blijft het zeer wenselijk een duidelijke indicatie te krijgen. 


\section{Discussie}

Dit onderzoek is uitgevoerd onder 86 Nederlandse consumenten. Het onderzoek geeft een indicatie hoe consumenten reageren op het veranderen van de houdbaarheidsdatum op verpakkingen en hoe dit effect heeft op hun weggooigedrag. Omdat het om een relatief kleine groep consumenten gaat welke zijn geselecteerd uit het Wageningen UR Smaakonderzoek Panel, kan niet gesproken worden over een representatieve steekproef die "de" Nederlandse consument vertegenwoordigd.

De experimenten zijn uitgevoerd in een gecontroleerde omgeving. Er is geen onderzoek gedaan naar weggooigedrag o.b.v. kilogrammen die in de vuilnisbak belanden, maar naar het selecteren van producten die de respondenten weg zouden gooien in de experimentele setting. Er kunnen dus geen uitspraken gedaan worden over hoe huishoudens daadwerkelijk reageren indien de termen aangepast gaan worden in de praktijk. Of consumenten een product weggooien hangt waarschijnlijk van veel meer factoren af dan alleen de houdbaarheidsdatum op de verpakking. Deze zijn in dit onderzoek niet meegenomen. Vervolgonderzoek zou kunnen ingaan op de wisselwerking van diverse drijfveren van consumenten om voedselproducten weg te gooien, en hoe dit valt te beïnvloeden.

Het onderzoek heeft laten zien wat mogelijke veranderingen kúnnen zijn, bij het wijzigen van terminologie. Om het daadwerkelijke gedrag te kunnen vaststellen, kan er gebruik gemaakt worden van diverse onderzoeksmethodieken in een 'real-life' setting. Daarbij kan er voor een opzet gekozen worden waarmee kwantitatieve resultaten behaald kunnen worden. Dit onderzoek beperkt zich daarmee tot een kwalitatieve verkenning, die ingaan op aantrekkelijkheid van het wijzigen van het gebruik van de huidige houdbaarheidsterminologie en het veranderingen in het voorgenomen weggooigedrag door consumenten.

Binnen dit onderzoek is er gekeken naar het effect van verschillende type houdbaarheidsdata van lang houdbare producten op voedselverspilling. Hiervoor is een bepaalde selectie gemaakt. Het aandeel van lang houdbare producten op voedselverspilling is relatief klein t.o.v. verse producten en bereide maaltijdresten. Om de voedselverspilling in zijn geheel terug te dringen zullen ook deze productencategorieën meegenomen moeten worden in onderzoek.

Tot slot is er de invloed van de (Europese) wetgeving. Niet alle aanpassingen aan het etiket zijn zomaar mogelijk. Hier zal dus rekening mee gehouden moeten worden bij de implementatie van een alternatieve term of het weglaten van de houdbaarheidsdata op producten.

Dit onderzoek levert waardevolle aanvullende inzichten over de aantrekkelijkheid van alternatieve termen, en waarmee in ieder geval is aangetoond dat het weglaten van houdbaarheidsdatum voor lang houdbare producten niet zondermeer wenselijk is vanuit perspectief van de consument. 


\section{Conclusies}

Uit dit indicatieve onderzoek is gebleken dat lang houdbare producten door respondenten minder weggegooid worden indien er geen THT datum op de verpakking staat (gemiddeld $-12 \%$ ).

Dit percentage is een gemiddelde van de 20 productcategorieën die meegenomen zijn in dit onderzoek.

Uit de resultaten t.a.v. het inzetten van alternatieve terminologie kwam naar voren dat respondenten 31\% minder weggooien indien de term "Lang houdbaar" op de verpakking staat. (Zonder vermelding van een specifieke datum). De term "Kwaliteit gegarandeerd tot [datum]” leidt ook tot 5\% minder producten weggooien. Er zijn echter ook alternatieve termen waardoor respondenten geneigd zijn om juist meer weg te gooien "Geproduceerd op [datum]" (+6\%) en "Best te gebruiken voor [datum]” ( $+4 \%)$. Met de term "Na [datum] kijken, ruiken en proeven" wordt er evenveel weggegooid als met de huidige term "Tenminste houdbaar tot [datum]".

Hoewel respondenten minder gaan weggooien geven ze echter aan dat ze de term "Lang Houdbaar" niet prettig vinden, omdat het hen geen duidelijkheid biedt over de voedselveiligheid en kwaliteit van het betreffende product. Deze onzekerheid blijkt een belangrijke invloed te hebben op het weggooigedrag van consumenten: kan ik dit product nog veilig eten en smaakt het wel goed? Zowel het weglaten van houdbaarheidsdata als het invoeren van een alternatieve term zou kunnen bijdragen aan het verminderen van voedselverspilling bij huishoudens. Het verdient aanbeveling om invoering hiervan gefaseerd te laten plaatsvinden. Het onderzoek wees namelijk uit dat bij een deel van de onderzochte productgroepen (suiker, rijst, meel, thee e.d.) respondenten deze onzekerheid niet ervaren. Bij deze producten lijkt het inzetten van de term "lang houdbaar" veelbelovend. Daarnaast dient aandacht te worden besteed aan het veranderen van de risicoperceptie van consumenten. Hiertoe zijn diverse mogelijkheden denkbaar, waaronder betere consumentenvoorlichting, informatievoorziening op de verpakking van het product zelf (evt. via QRcodes/smartphone applicaties). Hoe dit precies invulling zou moeten krijgen, zal verder onderzoek moeten uitwijzen. 


\section{Referenties}

EC Directive 1169/2011, 2011. Verstrekking voedselinformatie aan consumenten. Hierin Bijlage X: Datum van minimale houdbaarheid, uiterste consumptiedatum en datum van invriezing.

FAO, 2013. Food wastage footprint: Impacts on natural resources.

TNS Political and Social, 2015. Flash Eurobarometer 425: On food waste and date marking. Commissioned by EC DG Santé.

Motivaction Research \& Strategy - Keuchenius, C. \& Van der Lelij, B., 2015. Quickscan 2015: eetpatronen van verschillende sociale milieus, duuraamheid en voedselverspilling. I.o.v. Voedingscentrum.

Voedingscentrum - C. van Dooren \& Mensink, F., 2014. Voedselverspilling door consumenten: Factsheet.

Voedingscentrum en GfK - Temminghoff, M \& Damen, N., 2015. Voedselverspilling 2-meting.

Wageningen UR Food \& Biobased Research - Vollebregt et al., 2016. Monitor voedselverspilling update 2009-2014. 


\section{Bijlage 1 Coverstories}

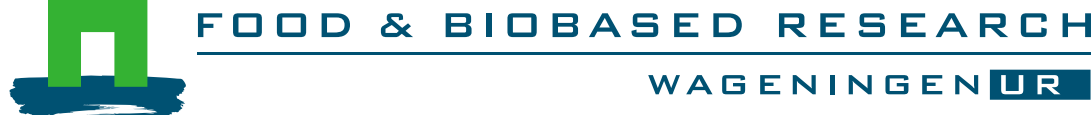

Coverstory 1

Beste deelnemer,

Leuk dat je mee wilt doen aan deze studie.

Je gaat zo naar het huis van een goede vriend van je.

Je vriend is onlangs op wereldreis gegaan en hij heeft nu besloten om langer weg te blijven. Hij heeft nog geen idee wanneer hij weer terugkomt. Hij heeft jou daarom gevraagd om zijn keukenkastjes helemaal leeg te maken. Aan jou nu de taak om de producten uit zijn keukenkastje te bekijken en in te delen in de volgende 2 categorieën:

- $\quad$ Dit product moet weggegooid worden, want kan je niet meer eten

- Dit product kan bewaard blijven en neem ik mee naar huis om zelf op te eten of om aan anderen te geven.

De producten die je wilt weggooien mag je in de vuilniszak stoppen of erbovenop leggen. De producten die je wilt bewaren mag je in het kratje stoppen.

Let op! Het is niet de bedoeling dat je verpakkingen open makkt!

Op de verpakkingen staan verschillende houdbaarheidsdata. Als een houdbaarheidsdatum is afgeplakt of doorgestreept dan is er van dit product geen houdbaarheidsdatum bekend.

Als er nog vragen zijn dan horen we dat graag.

Heel veel succes! 


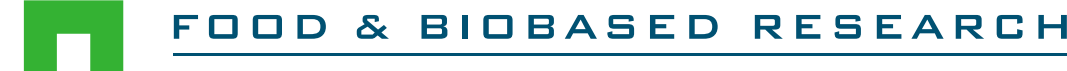 \\ WAGENINGEN UR}

Coverstory 2

Beste deelnemer,

Leuk dat je mee wilt doen aan deze studie.

Je gaat zo naar het huis van je oma/moeder.

$\mathrm{Je}$ oma/moeder is opgenomen in een zorghotel en het is nog onduidelijk wanneer ze weer terugkomt. Ze heeft jou daarom gevraagd om haar keukenkastjes helemaal leeg te maken. Aan jou nu te taak om de producten uit haar keukenkastje te bekijken en in te delen in de volgende 2 categorieën:

- $\quad$ Dit product moet weggegooid worden, want kan je niet meer eten

- $\quad$ Dit product kan bewaard blijven en neem ik mee naar huis om zelf op te eten of om aan anderen te geven.

De producten die je wilt weggooien mag je in de vuilniszak stoppen of erbovenop leggen. De producten die je wilt bewaren mag je in het kratje stoppen.

Let op! Het is niet de bedoeling dat je verpakkingen open maakt!

Op de verpakkingen staan verschillende houdbaarheidsdata. Als een houdbaarheidsdatum is afgeplakt of doorgestreept dan is er van dit product geen houdbaarheidsdatum bekend.

Als er nog vragen zijn dan horen we dat graag.

Heel veel succes! 
Coverstory 3

Beste deelnemer,

Leuk dat je mee wilt doen aan deze studie.

Je gaat zo naar het huis van een goede vriend van je.

Je vriend gaat binnenkort op wereldreis en hij heeft besloten zijn kamer gedurende een half jaar in onderhuur te doen. Daarom moeten zijn keukenkastjes helemaal leeg. Jij mag alles hebben wat er in staat, want hij heeft hier toch niks aan op vakantie. Aan jou nu de taak om de producten uit zijn keukenkastje te bekijken en in te delen in de volgende 2 categorieën:

- Dit product moet weggegooid worden, want kan je niet meer eten

- Dit product kan bewaard blijven en neem ik mee naar huis om zelf op te eten of om aan anderen te geven.

De producten die je wilt weggooien mag je in de vuilniszak stoppen of erbovenop leggen. De producten die je wilt bewaren mag je in het kratje stoppen.

Let op! Het is niet de bedoeling dat je verpakkingen open maakt!

Op de verpakkingen staan verschillende houdbaarheidsdata. Als een houdbaarheidsdatum is afgeplakt of doorgestreept dan is er van dit product geen houdbaarheidsdatum bekend.

Als er nog vragen zijn dan horen we dat graag.

Heel veel succes! 